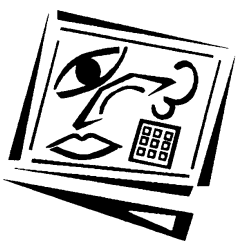

\title{
Grappling with technology: A case of supporting Malaysian Smart School teachers' professional development
}

\author{
Thang Siew Ming \\ Universiti Kebangsaan Malaysia \\ Puvaneswary Murugaiah \\ Universiti Sains Malaysia \\ Lee Kean Wah \\ Universiti Malaysia Sabah
}

Hazita Azman, Tan Lay Yean, Lee Yit Sim

Universiti Kebangsaan Malaysia

\begin{abstract}
This paper discusses the challenges faced by a group of Smart School teachers in a partnership model designed to help them develop professionally through the use of online tools. This model known as e-CPDelT: Model 2020 is loosely based on the successful, UK based Improving the Quality of Education For All (IQEA) project (Hopkins et al., 1996). The model was piloted on 20 teachers of English, mathematics and science from 5 Smart Schools around Kuala Lumpur. It features collaboration between these teachers in the hope that it would lead to the development of viable communities of practice. Teacher collaboration in this pilot was in the form of (a) sharing text based narratives of perceived good lessons through blogs and (b) sharing of video clips of good lessons through the ViP (Virtual interactive Platform) and (c) forum discussions of lessons. Data were obtained from teacher interviews and mentor reflections. Brinkerhoff's (2006) framework on technology adoption was used to identify the challenges faced by these teachers. The findings revealed that teachers faced resource, institutional, informational and attitudinal problems. The paper concludes with discussion of suggested measures to improve technology adoption by teachers.
\end{abstract}

\section{Introduction}

The online Continuing Professional Development for Teachers (e-CPDelT) project provided an online platform for twenty teachers from five Smart Schools to share experiences, knowledge and skills in order to develop learning opportunities for each other. In this project, members of online communities of practice (CoPs) interacted by (a) sharing through blogging, where perceived good lessons were shared and exchanged, (b) sharing and viewing of video clips of good lessons through the ViP (Virtual interactive Platform) and (c) participating in forum discussions of lessons. These online tools provided opportunities for teachers to improve their instructional practices and ICT skills through interactions with other teachers.

Preliminary studies by Thang et al. (2009a \& 2009b) revealed that the twenty Smart School teachers were keen to participate in the project. However, the teachers also 
requested more frequent support from mentors and also more ICT training. They also expressed their need for further emotional support and a lesser workload to cope with the pending tasks. These were worrying findings. In view of that, the project team undertook to monitor the progress of these teachers closely and to provide frequent support in the form of regular workshops and opportunities for them to interact with their mentors frequently. Despite that, the desired CoPs were not established at the end of the one-year period of the pilot project. Therefore, the barriers that could have impeded the project's progression must be examined. In line with this, the present study focuses on barriers arising from the adoption of online tools used in the project. Thus, the aim of the study is to seek answers to the following research questions:

1. What are the challenges and problems faced by Smart School teachers in using the online tools introduced to share their teaching practices?

2. What are the lessons learnt regarding the use of technology in promoting continuing professional development among these teachers?

\section{The Smart School reform}

The Malaysian Smart Schools were intended as flagships of educational change serving as centres of excellence for schools in their locality. They are commonly known as Sekolah Bestari and most recently as K-schools or Knowledge-based schools. The goal of this project was not only to equip students with IT competence and science and technology, but also to bring about a systemic change in education, from an examdominated culture to a thinking and creative knowledge culture (Ministry of Education, 1997). 4 subjects (English Language, Malay Language, Science and Mathematics) were selected to be taught the smart way (Ministry of Education, 1997) and a total of 90 schools were involved in the pilot phase. Though the government has now moved on to the concept of cluster schools, Smart Schools are still in operation and many are now participating in the new cluster school project. Cluster schools comprise a group of schools working together as a team to achieve a common goal. This concept was adopted not only to discourage rivalries among Smart Schools but more importantly to promote the spirit of sharing of resources and know-how among them. Each cluster is linked to an institute of higher learning; a concept which is in tandem with that of the e-CPDelT project.

To ensure the success of the Smart School reform, teachers have been provided training and courses by the Ministry of Education to upgrade their knowledge, competence and efficiency. Training programs such as Computer in Education, Computerisation, and Use of Computers in the Teaching and Learning of Bahasa Melayu (the Malay Language) were held at teacher training colleges and local universities. They were designed to equip teachers with skills required for teaching in a technologyenriched environment and to minimise teacher resistance to the change process (Ministry of Education, 1997). Smart Schools were also generally well-equipped with computers and accompanying peripherals such as computer labs, LCD projectors and WIFI hotspots. Teachers were provided laptops. It was the hope of the government that with the necessary training and equipment, teachers would utilise the newly acquired skills in their teaching activities.

However, studies have shown that the utilisation level has only been moderate. Hajar Mohd. Nor (2005) found a lack of technological skills among teachers despite the training. According to her, teachers described their training as having failed to address 
their real needs - about "how" and "when" to use technology in their lessons. In another related study, Mokhtar Hj. Nawawi et al. (2005; p. 88) highlighted a number of factors, including inadequate financial support, insufficient time for teachers to develop lesson plans using computers, and the lack of accessibility to and availability of computers and peripherals, as hindrances to the utilisation of computer based technology by teachers. Further, studies by Jaber et al. (1999), Sham Ibrahim (2003) and Mokhtar Hj. Nawawi et al. (2005) revealed that many teachers simply did not want to use computers for teaching even when they were available. This was because they were not committed to the cause. Neither was there any commitment from the school administrators. Their findings support Ely's (1999) view that the relationship between commitment and leadership is important as the two factors are prerequisites for the successful implementation of innovations. This was upheld by Adey (2004) who cited studies such as Guskey \& Huberman (1995), Bullough et al., (1998), Borko et al., (2002), Fullan \& Steigelbauer (1991), Joyce \& Weil (1986), and Joyce and Showers (1988) to support his claim that institutional support is necessary for the successful implementation of technology.

In the Smart School scenario, the Ministry of Education identified teacher professional development as a top priority, especially since it aims to convert all 9,000 public schools into Smart Schools by 2010. However, the lack of training in ICT use in teaching and learning, as reported by a benchmark study on Smart Schools across 9 nations (Frost \& Sullivan, 2004), has forced policy makers to shift focus from bridging the digital divide to bridging the fluency divide as the emphasis is now on how able is one in using the various affordances that web resources have to offer. Additionally, their study recognised the need to develop communities of practice, comprising collaborative networks of students, teachers, schools, industries and education developers, through professional development platforms to ensure sustained engagement and applications of IT in a 'smart' society (p. 48). Thus, the e-CPDelT project is timely as it proposes a continuous professional development platform that has the potential for engaging teachers in an online collaborative learning environment.

\section{The e-CPDelT Vision 2020 project}

Besides developing communities of practice (CoPs) among Smart School teachers to enable sharing of teaching and learning practices, this project also aimed to help teachers to improve their ICT skills and motivate them to actively use these skills in their lessons. It employed a partnership model for online CPD in training teachers of all disciplines. In this project, teacher participation was limited to only teachers of English, mathematics and sciences. However, in the near future it is hoped that the model would be extended to mainstream school teachers.

The e-CPDelT project was based on the Improvement Quality Education for All (IQEA) action research framework which has been extensively used in the UK as a vehicle for school improvement. In the IQEA project, teachers (in groups of 6-8) meet and work together to bring about changes in their respective schools by reflecting on and sharing their teaching practices (Hopkins et al., 1996). The model it employed was the Continuing Professional Development (CPD) hub and spoke model based on a critical relationship between a number of school-based cadre of change agents (spokes) and a higher education institution (HEI)-based research team (hub). Figure 1 illustrates the CPD hub and spoke model used in the eCPDelT project. 


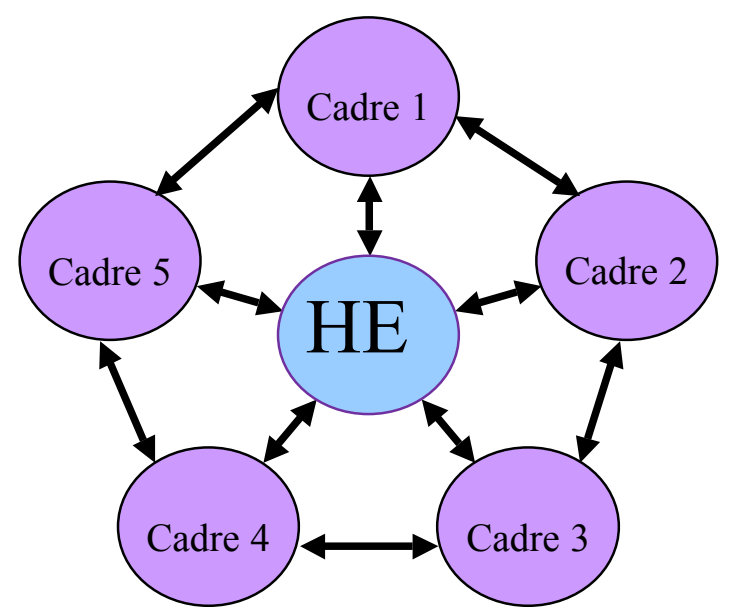

Figure 1: The CPD hub and spoke model in e-CPDelT

The spokes are the five schools with four teachers (of English, mathematics and science) from each school while the hub is the researchers from the higher education institutes (HEI), namely from three universities: The National University of Malaysia (UKM), University of Nottingham, UK and University of Sabah, Malaysia (UMS). The HEI research team brought together the school-based cadres to share emerging issues, themes and evaluation in order to develop expertise in managing change in their own schools and beyond. It aimed to achieve this by developing communities of practice among the cadres.

\section{Relevant literature}

The crux of the study concerns the use of technology in promoting teacher professional development. According to Day (1999), professional development (PD) involves both naturally occurring learning experiences and planned activities that benefit an individual, group or school. Teachers, as change agents, acquire and develop knowledge and skills to improve the quality of education in the classroom.

Lee (2007) posited that PD systems generally can be categorised into two major forms based on the principles and characteristics underpinning them, i.e., a dominant form that is 'knowledge and skill transmission-oriented' (KSTO) PD, and an alternative form that is 'community of practice oriented' (CPO) PD. In the former, knowledge is transmitted from external experts to teachers without taking into account teachinglearning contexts. Moreover, teacher learning, which involves the accumulation of skills, is passive. Immediate changes are expected from this form of PD. In the latter, on the other hand, teacher learning is through collaboration, thus relying on internal expertise. Learning is active and context dependent. Long term changes are expected as lasting change is a slow process (Lee, 2007).

Effective teacher professional development (TPD) features various elements. The work by Garet et al. (2001) on effective TPD is of particular relevance to this study. Garet et al. (2001) carried out a study on a national sample of PD programs involving 1027 
mathematics and science teachers. Using a variety of data sources elicited via interviews, survey, case studies and classroom observations, they investigated the effectiveness of a PD system in bringing about a positive change in the practice of secondary teachers. This was done in terms of the PD system's two main 'features' (structure and core), and, within each of them, the three related 'components', as shown in Table 1 below.

Table 1: Key features of effective TPD based on Garet et al. (2001)

\begin{tabular}{|c|c|c|}
\hline Features & Components & Descriptions \\
\hline \multirow[t]{3}{*}{ Structural } & Model type (form) & $\begin{array}{l}\text { ‘Reform' vs. 'traditional' PD (study groups, teacher } \\
\text { network, mentoring relationship, etc. vs. traditional } \\
\text { workshops and conferences) }\end{array}$ \\
\hline & Duration of the activity & Number of hours and span of time \\
\hline & Collective participation & $\begin{array}{l}\text { Participation by established groups (teachers from the } \\
\text { same school, department, grade level vs. individual } \\
\text { teachers from many schools) }\end{array}$ \\
\hline \multirow[t]{3}{*}{ Core } & $\begin{array}{l}\text { Focus on content } \\
\text { knowledge }\end{array}$ & $\begin{array}{l}\text { The degree to which the PD system activity is focused on } \\
\text { deepening teachers' knowledge of the subject matter and } \\
\text { how students understand and learn it. }\end{array}$ \\
\hline & Active learning & $\begin{array}{l}\text { Meaningful analysis of teaching and learning (e.g., } \\
\text { examining student work, getting feedback on teaching) }\end{array}$ \\
\hline & Coherence & $\begin{array}{l}\text { Building on what teachers already have learned, aligning } \\
\text { PD with state and district standards and assessment, and } \\
\text { encouraging communication among teachers who are } \\
\text { striving to inform their instruction in similar ways. }\end{array}$ \\
\hline
\end{tabular}

Garet et al. (2001) concluded that to improve PD, 'it is more important to focus on the duration, collective participation, and the core features (i.e. content, active learning and coherence) than type' (p. 936). In terms of core features, it was found that PD 'activities that are linked to teachers' other experiences, aligned with other reform efforts, and encouraging of professional communication among teachers', appeared to support change in teaching practice (p. 936). In other words, when the structural components are optimally primed, they create a conducive environment for the core components of PD to emerge. It is the core features that lead to change in knowledge and skills and ultimately to change in practice.

In the case of the eCPDelT project, the type of PD undertaken was the CoP oriented PD featuring collective participation and active learning that builds on teachers' prior knowledge. Hence, it portrayed the structural and core features presented by Garet et al. (2001). Two main principles of Garet's et al. study underpinned the development of the e-CPDelT project. Firstly, the project was developed based on the understanding that the more time teachers spend on PD, the more significantly they can change their practice (Borko \& Putnam, 1995). Secondly, collective participation, which involves PD designed for groups of teachers, created more active learning contributing to enhanced teacher knowledge and skills (Holland, 2005).

Through the eCPDelT project, it was hoped that teachers would acquire technological pedagogical content knowledge (TPCK) as proposed by Mishra and Koehler (2006). Teachers learn about educational technology and develop pedagogical understandings by engaging in collaborative groups (ibid, p. 97). This approach would go beyond the simple acquisition of skills as it addressed the pedagogical integration of technology. 
Technological and social resources are needed for teachers to develop deep knowledge and skills shaped by new collaborative practices (BECTA, 2009). These factors need to be reflected in the learning practices of the teachers themselves. In the eCPDelT project, technological and social resources were the online interactive tools. Through blog and ViP entries as well as discussion forums, teachers interacted with one another to develop TPCK. So how does the use of technology impact on TPD? Before answering this question, it is vital to understand technology acceptance. There are various models and theories to explain user technology acceptance: Technology Acceptance Model (TAM) (Davis, 1989), Computer Self-Efficacy (Compeau \& Higgins, 1995), Task-Technology Fit (Goodhue \& Thompson, 1995), Motivational Model (Davis et al., 1992) and adapted Theory of Planned Behaviour (Mathieson, 1991).

These models have contributed to our understanding of user acceptance perceptions and behaviours. In TAM, for example, intention of use is central. The perceived usefulness and perceived ease of use determine acceptance. Compeau and Higgins (1995), on the other hand, postulated that computer self-efficacy, a belief of one's capability to use the computer, is associated with attitudes towards computer technologies. Thus, participants with little confidence in their ability to use computers might perform more poorly on computer based tasks than others who are confident. In recent times, a unified theory of acceptance and usage of technology was proposed by integrating enablers or moderators. Venkatesh et al. (2003), for instance, emphasised the importance of experience, gender, age and voluntariness in enhancing understanding of technology adoption. Sun and Zhang (2006) included two other moderators: nature of task and nature of technology.

A large body of work is therefore, available on technology acceptance. Yet, it is not exhaustible. It is not possible to come up with the 'perfect' model to measure technology adoption or abandonment. As Sun and Zhang (2006) pointed out, problems associated with technology adoption may be so dependent on complex contextual factors that they are beyond researchers' reach. Recognising this reality, the present research employs Brinkerhoff's (2006) model in investigating the barriers that hinder technology adoption. This model is specifically designed to check barriers that can contribute to under-utilised technology resources and the lack of integration of these resources in instructional practice.

\section{Framework of study}

The four barriers identified by Brinkerhoff (2006) that would impede technology adoption are resources; institutional and administrative barriers; institutional barriers relating to training and experience; and barriers related to teachers' attitudes and fear. Resource barriers are issues related to tools and their application. They include technology related problems, insufficient computers, peripherals and software licenses, outdated hardware or software, limited Internet access, as well as slow or intermittent Internet connections. Institutional and administrative barriers relate to contextual and cultural factors, teaching schedules and time constraints. Barriers relating to training and experience, on the other hand, include lack of or poorly structured PD activities that focus on technology integration, inconvenient training times, irrelevant training activities and lack of continuous support following PD. The last category is attitudinal and fear related barriers, which encompass anxiety concerning technology use as well as teacher perceptions of their computer competency and adequacy of preparation. 


\section{Research methodology}

The technology employed in the eCPDelT project involves blogs and the ViP. To examine the problem and challenges faced by the teachers in undertaking the various activities of the project, focus group interviews were conducted on the mathematics, science and English participating teachers.

Besides that, the three main mentors from the three groups and the overall mentor who was the IT support coordinator were asked to reflect on the problems and difficulties faced by the teachers and record their reflections. Both the interview data and reflections were analysed according to the categories derived from the framework of this study. Each category was divided into themes, as listed in Table 2. The themes were limited to those which were appropriate for the present study.

Table 2: Themes for data analysis

\begin{tabular}{|l|l|}
\hline \multicolumn{1}{|c|}{ Categories } & \multicolumn{1}{c|}{ Themes } \\
\hline Resources & $\begin{array}{l}\text { Technical glitches, limited Internet access, slow or } \\
\text { intermittent Internet connections }\end{array}$ \\
\hline Institutional and administrative barriers & Workload, time factor, contextual factors \\
\hline $\begin{array}{l}\text { Barriers related to training and } \\
\text { experience }\end{array}$ & $\begin{array}{l}\text { Lack of support from school, insufficient support and } \\
\text { information given by research team }\end{array}$ \\
\hline Attitudinal and fear related barriers & $\begin{array}{l}\text { Negative perceptions about technology competence } \\
\text { and adequacy of training, fear of embarrassment }\end{array}$ \\
\hline
\end{tabular}

\section{Description of online tools}

The first online tool used was Google blogs. Teachers were asked to select and comment on two teaching episodes, one which they considered to have been successful and another which they considered to be less so, and post them in the blogs. This was to stimulate the teachers' interest and hopefully it would lead to self disclosures which might help to bond the group. The tasks were deliberately designed to be open so that teachers were free to respond to them in any manner they chose. They were required to post their blog entries based on the tasks and later respond to other postings in the discussion forum.

The second online tool utilised was the Virtual Interactive Platform (ViP), a tool which would enable them to share video clips of their classroom activities online. The ViP is a technological tool developed by a team of researchers from the School of Education, University of Nottingham to support teacher professional development. It allows users to upload videos to the ViP server and construct a text based narrative around this. It further allows the distribution of 'home made' video footage of classroom events or episodes and posting of personal commentary and reflection of the recorded episodes. This would give the teachers a chance to add their own commentaries; describe the particular aspects of practice being shown; outline the aims of the lesson, the rationale for the approach, the strategies used and so on (Thang et al., 2009a). For this research project, the participating teachers were requested to upload selected video clips of a lesson in which they had integrated the use of ICT. These clips could highlight successful or problematic use of IT as perceived by the teachers themselves. The 'excerpts' were then discussed among the online community or cadre in subject groups. Research has shown that making reflective videos can benefit teachers who want to reflect deeply on their current practice (Barton \& Haydn, 2006; Gebhard, 2005). 


\section{Research procedure}

As the eCPDelT project involved teachers from different schools, it was vital to ensure the teachers were comfortable with one another. Two ice-breaking sessions were held in September 2008 to introduce members of the research team to the teachers in a friendly and informal manner. They were briefed about the aims and objectives of the project and informed about forthcoming training workshops. In November 2008, a face to face workshop was conducted for the teachers. It focused on the blogging activity. Teachers were provided hands on training regarding the blogsite that was specifically designed for the project. They were also briefed on the assignment, procedure and their role. The deadline for blog entries were mutually agreed by both the teachers and mentors. Besides that, the teachers were also introduced to the ViP. As it is a new tool to them, a step by step presentation and a manual on how to use the ViP was provided.

Another face to face brainstorming workshop was held with the 3 subject groups in April 2009 to elicit their views about the blogging activity. The first focus group interview regarding the blogging activity and their participation in the project was also conducted then. It was during the interview that the teachers expressed their concern about the use of the ViP. They disclosed that they needed more time and guidance to comprehend how to use it. Consequently, another workshop was held in July 2009 whereby a hands on session using the ViP was provided. The second focus group interview was held during the workshop to elicit teachers' views regarding the ViP activity.

\section{Analysis of data}

The data sources used for the study were interviews and mentor reflections. Two focus group interviews were carried out with each of the three subject cohorts regarding the use of the technological tools. As mentioned earlier, Brinkerhoff's (2006) categories of barriers that can hinder the effectiveness of technology PD underpinned this study. Themes relevant to the current study were formulated for each category (see Table 1) and the analysis of data was guided by these themes. Texts from both the interviews and reflection transcripts were matched with the themes.

\section{Resources}

It can be gleaned from the transcripts that all the teachers faced problems in using the ViP. Some of the more persistent problems are described below.

E3: I have done the video clips but I have problems in shortening the video clips in my movie maker. ... My movie maker will suddenly disappear. Every time I try to cut it short, it will close up. I have problems with the movie maker.

E1: I have done the clips. But after I listen to them, I couldn't hear anything. So I thought something is wrong and I just stopped there. I did a few recordings. I listened to them but I cannot hear. Something is wrong with the volume.

S4: The problem is when I want to edit the video, technical problem, we want to edit the video, and then we want to import the video, we can open the video, we can see what happen but when we want to import, to edit it, to using the movie maker, then problem. Instead, we have to install for that. 
M2: And then the part of using the video cam was also a problem. Uploading was a problem.

Upon closer scrutiny, it was revealed that only about $30 \%$ of the teachers tried very hard to overcome their problems with the ViP.

S4: I tried, I take the reader, the card reader and transfer directly to the laptop using another teacher's laptop, still nothing, we cannot use the cable I think.

S5 added: That's what I suppose. I tried using a few PCs, I even use my own laptop to do it at home, cannot.

The majority of them gave up readily:

S6: For me I didn't try it, because before I could try it, I already heard rumours cannot do, cannot do, cannot do, so I didn't try out. There were so many problems after this, so many problems, so I didn't try it. I even had problems transferring the video that I record using the videocam to transfer into the computer. I can't view it.

M4: But frankly speaking, E4, who is more IT savvy, she went in first and she tried to upload. And when the moment she told us that there were a lot of problem... oo a lot of problem... so I wait for her to solve the problem and I will do the rest later! So everytime I'll ask her "... can or not ... can or not" She said "Problem lah .. cannot view lah" So .. ok.. ok .. cannot view don't waste time I got other things to do. So I just left it as it is...

However, all of them had very few problems with the blogging activity. Their only complaint was that it was not very user friendly as it did not feature an alerting system.

\section{Institutional and administrative barriers}

All the teachers highlighted lack of time as a barrier to them using the tools actively. They pointed out that they not only had teaching responsibilities but also duties such as co-curricular, administrative and other responsibilities. M4 and E1 expressed this vividly:

M4: ... because I feel recording and all that .. its not that we don't want to do .. we are also struggling time .. frankly speaking we are so struggling with time .. like myself if you tell me .. if you have to record and upload, I will see what is the minimum requirement, once enough, twice enough, I'll just do the minimum requirement and I done with it.

E1: Yeah...I read, I did my part. When checking my e-mail, I also go into the blog site to see whether there's anything new or not. Time constraint is there... I can't get the time at school. In school there's a lot of paper work to do. I can't even find time to mark. I've to mark at home. A lot of paperwork...I think you all will agree with me. A lot of paperwork to do nowadays. Actually I do wish to comment. I just hope there'll be holidays, when I can just sit down and comment. I just can't get the time.

This problem has to be understood within the context of the Malaysian Education system. As pointed out by Bismillah Khatoon Abdul Kader (2007), the education system in Malaysia is very examination-oriented. A school's performance is judged based on its achievement in public examinations. Teachers' efforts are concentrated on preparing their students for public examinations. Thus, attempts to make lessons creative, interesting and learner centred by using technology are hampered by the 
perpetual need to focus on teacher centred lessons aimed at covering the syllabus and preparing students for forthcoming examinations. This was explicitly voiced by the following teachers.

E1: ...Because this year I'm teaching Form 3 and Form 5. I find there's time constraint. Time constraint is there...teaching 2 levels, English and EST. I feel I've got a lot of preparation to do because I've not taught Form 3 for a couple of years. ...I need to think about the ideas as I don't use so much of ICT in the class this year because for exam levels [Forms 3, 5] we don't really bring them to the lab. It's only with the Forms 1,2 and 4 and I don't have these classes this year.

S3: Because I concentrate on my teaching because this is the first time I'm teaching Form 5 Biology. There's a lot of pressure on me. I've got to prepare the teaching materials. So sometimes I'll do until midnight. So it is hard to find the time to do blogging.

\section{Institutional and organisational barriers related to training and experience}

The teachers participating in this project were not adequately supported by their schools despite initial agreement by the principals to give these teachers their full support. Not only was their workload the same, consideration was also not given in accessing computers. The English mentor lamented:

Their (the teachers) work environment does not permit them to delve in it during their free time at school. They are inundated with work that they view their task (using the ViP) a chore than an aid.

Thus, despite ample support from the research team, which they candidly admitted, the teachers were not able to participate actively.

S5: Sometimes we are not actively involved in this programme. Sometimes we feel sorry also. The mentors are doing their great job for us. Give them a call and they will try to attend us and help solve our problems. So sometimes I feel bad lah. It's just that, actually I want to be involved in this programme, actively, but just don't have the time to do it. And then with the problems, just give up.

Another problem that hindered active participation was the fact that the teachers were teaching different levels and in the case of the science teachers, they were of 3 different disciplines (i.e. biology, chemistry and physics). Hence, they faced difficulties in sharing their problems with each other. These were brought up by the teachers, for example:

E1: I think one of the things is we are all teaching different levels. Sometimes when we want ideas, we realize our friends are not teaching that particular level. They can't give us ideas for that level.

S2: My problem is I can't comment on other people's work because they major different subjects. They teach Chemistry, Biology. For me, I'm teaching the lower forms and the Science for lower forms is very basic and so I don't need to go into details. Very big difference.

M4: So I feel that in this group we have teachers from various level, various forms, I think we are not all teaching Maths .. although we belong to the Maths panel, but for myself I am more to Add Maths. So when you are involved in hands on or something .. you are more comfortable with something to do with Add Maths and someone has posted anything related to Add Maths and it interests me of course I will respond. 
This was a problem not foreseen by the research team and hence, was a limitation of the study. Informational barriers were also evident. The main problem confronting the teachers was uncertainty regarding their role in the tasks. They were sometimes uncertain of what was required of them and were concerned that they were not doing the tasks correctly:

E1: When we saw member X's comments, we thought that's what's expected of us. I printed to make sure mine is structured like hers. I was afraid if I were to write something simple, it's way far from her standard. I printed out the tasks and was wondering how to write....must be long and formal.

A further complaint was that the task was too prescriptive.

E2: I think we must not be rigid that it must be lessons that incorporate ICT. It can be anything.

M1: What you want to put in the blogs can be anything, not necessarily ICT-based lesson.

In actuality, teachers were allowed to share non ICT-related lessons. However, this was not clearly explained to the teachers.

\section{Attitudinal and fear related barriers}

Both the interview and reflection transcripts revealed that individual teacher factors, namely attitude and fear, affect their use of technology. This was evident in more than $60 \%$ of the teachers. Some of these teachers had a negative perception of their online competence. As a result, they were not motivated to use the tools:

E1: ...that takes time because I'm not that well-versed with ICT. So it takes time for me
to come up with ideas.

E1: More so like me. I'm not an IT person. For any technology problem, I say [to my students] 'I can't help you with the problem, can you share the computer with a friend'.

M4: Okay, to start off this, I must say that involving myself in IT is not my cup of tea lah .. but I did try, to log in to VIP ..

M1: Maksudnya macam susah .. mungkin saya bukan aktif nak bukak internet .. kalau orang yg amat suka computer, buka internet mungkin dia senanglah, tapi sebab saya jarang buka internet jadi rasa takde fungsi sangat ..

[Translation: It's difficult... maybe I'm not an active user of the Internet...for those who love computers, it's not a problem to access the Internet, but because I seldom browse the Internet, I feel it's not so valuable...]

However, there were some who used the Internet frequently and thus had no problem with the blogging activity. This was the group of teachers who were disappointed with the lack of participation from the rest. As M1 pointed out:

M1: Kalau semua orang aktif., maknanya kita pun akan respon lah, tapi hari tu tengok macam .. last M4 kan, pastu baru ada dua .. jadi kita macam .. orang tak buat jadi kita pun ... kadang kita tengok tengok juga tapi takdelah tambah apa2 .. sebab takde respond kan

[Translation: If everyone is active, we'll also respond...but the other day, after M4's response, there were two more, that's all... others don't respond, so at times I just go to the site but don't contribute anything.... as there's no response.] 
Fear was another barrier evident in those who were not frequent Internet users. E1 frankly admitted it:

I think the element of nervousness will be there. It's just like the Inspectorates coming to observe us. No matter how good our lesson is, how good we are, there'll be the element of nervousness (to use the ViP).

Another element of fear noted was the anxiety that their students were better than them. A teacher confessed:

E1: I do want to learn anything related to ICT because in my school the boys are so well-versed on ICT and MP3, MP4... they know all these terms and gadgets. You feel like they know so much more than you... you feel like you're left behind. So you try to be as close to them as possible to them. Of course, I accept the fact that I cannot be at the same level as them because they are good, they've exposed to it from young. But at least not too far from them.

Besides these, culturally-related attitudes seemed to have hindered the extent of technology use too. Malaysians generally do not want to be seen as disrespectful to others, which is culturally regarded as 'saving face'. Thus, making comments that may seem to cause one to lose credibility in the eyes of others ('losing face') is avoided. This was expressed by six teachers. Other teachers were in general agreement with them. M1: ...takut jugak kalau yang kita komen2 tu dia tak setuju ke ... so kadang2 kita
macam terima ajelah .. a.. komen sikit sikit aje
[Translation: ...scared that the other person does not agree with our comments...so
sometimes L just accept...if not just comment a little]

E3: I have this feeling that I do mind what people say. I don't mind other people's feedback, but if they to say something not so positive, I'd feel uncomfortable. And to comment on other people also, it's quite difficult for me. Because I think they would feel uncomfortable like I would. So my comments will all be positive comments.

E1: You do not know the personality of the other person whether he can be easily be offended or not. What if I say this...to me it's OK but what if to the other person it's not. The person is offended and does not like it.

S1: That's one of the reasons. We're worried that we are a bit show off, like as if we are so good, but we are not. ... and at the same time we are not comfortable with other people criticising us, they may say funny things.

The Science mentor also pointed out that this factor could be an obstacle that prevented these teachers from participating actively in the activities. She said:

That's what I was thinking too. Maybe that's the reason why... as Malaysians we don't want to come across as critical.

A teacher tried to reason this out:

E2: I think it boils down to being afraid to show our weaknesses. Not sharing because we're afraid that people will judge us. We think that people will analyse us, judge us... this shouldn't be done, they should not have a lesson conducted this way. Probably because of that, we are very careful of what we write. You see, we are not from the same schools, we do not know each other, their backgrounds. 


\title{
Discussion of findings and suggested solutions
}

It is apparent from the findings that teachers involved in the study faced several barriers in adopting the online tools employed in the eCPDelT project. The tools themselves, especially the ViP, were hindrances, which might have actually contributed to teachers' reluctance to adopt ICT. It appeared that some of the participants were 'frustrated' that the activities were not helping them enough. It was obvious that the teachers did not find the ViP user friendly. Hence, it should be replaced with a tool that is less complicated and easier to manoeuvre. Apparently, the $\mathrm{ViP}$ is more suitable for advanced learners who possess intermediate computer knowledge and skills. The 20 teachers in this study were definitely not ready for it. Hence, the ViP became more of a hindrance than a facilitating tool for the teachers' ICT development. The Science mentor succinctly summed up these problems. She said:

\begin{abstract}
The clips uploaded are too short \& brief to be meaningful. It is not possible to capture problematic sessions into ViP as those occur naturally. ViP can only record instances of sessions demonstrating only ordinary class usage. Hence no point in having them. Hence, there is nothing for the teachers to comment and as a result, they are not motivated to go online to give comments because they have nothing to say.
\end{abstract}

The problem of lack of time identified by Thang et al. (2009b) in a preliminary study persisted to be one of the major problems that affected the rate of progress of the project. This phenomenon was reported in several studies on the implementation of the Smart School initiative (c.f. Azian T.S. Abdullah, 2006; Cloke \& Sharif, 2001; Bismillah Khatoon Abdul Kader, 2007). Heavy workload is the attributive factor. These teachers constantly have to juggle with teaching responsibilities, administrative work and co-curricular duties. On top of that, they have to worry about their students not performing well in public examinations. Thus, it was not surprising that the teachers lacked interest and motivation to experiment with new methods of teaching.

Institutional and administrative barriers, such as the lack of support from schools, were also reported as barriers to the use of technology. As discussed earlier, individuals who are in leadership roles should be the first to show commitment as this is one of the prerequisites to the successful implementation of technology (Ely, 1999; Adey, 2004). This is particularly pertinent in the context of Malaysia where top-down directions and instructions have been the driving force behind many of the initiatives that have led to the progress and development of the country.

Weaknesses in the implementation of the online tools also contributed to the lack of success of the pilot project. Problems like mismatch between the teachers' class levels and specialisation, and lack of clear information exchange, however, can easily be rectified. Even more serious were attitudinal and fear-related factors. Kay (2007), in a review of 68 articles on technology and pre-service education, emphasised that computer attitude, ability, and use are the major dependent variables for technology adoption. The current study revealed instances of teachers not having the necessary technological knowledge and skills, and also being fearful of being embarrassed by their colleagues as well as their students. All these would undermine their confidence and interest in technology. Similar findings were found by O'Hanlon (2009). Hence, teachers' motivation and apprehensions for participation and sharing must be thoroughly examined. This is crucial to ensure more active use of technological tools and sustained participation (So et al., 2009). 
Numerous lessons are learnt from the study. Firstly, technological tools employed must be more user friendly. Ease of use and perceived usefulness can predict attitudes towards technology use (Davis, 1989; Hsu, Wang, \& Chiu, 2009; Moon \& Kim, 2001; Teo, Lee \& Chai, 2007). Thus, current activities and tasks have to be improved. Future instructions of given tasks should be clearer, more explicit and open ended to give teachers the opportunity to be more creative and adventurous. So et al. (2009) proposed that participating teachers should be given the opportunity to share their personal views on various issues such as professional development experiences, online communities, and teaching and learning with technology. They further suggested the possibility of engaging teachers as co-designers, that is, continuously engaging them in the design processes as informed participants. This suggestion is in line with the proposals of Brown and Duguid (2000), and Fischer and Giaccardi (2006). All these will be taken into consideration in the forthcoming project. In this new project a learning system will be devised which will provide online modules and online resources to help teachers develop professionally and improve their ICT skills. The modules will consist of sample interactive activities and tasks. Teachers are required to give feedback, discuss problems and share their experiences with fellow online participants. The teachers are not enlisted through schools but invited to participate on a voluntary basis and they do not have to reveal their names. This assures anonymity and will avoid embarrassment and "loss of face". The system is available free for all Malaysian secondary school teachers.

In conclusion, it has to be pointed out that despite its various weaknesses, the project was positively received by the 20 teachers. All of them have expressed their desire to participate in the forthcoming learning system. Thus, the e-CPDelT project has managed to successfully create a social space for these teachers to interact and share ideas towards improving their teaching practice. It has introduced a new way of learning and opened up an avenue that has vast potential for self and professional improvement and development. Hence, problems encountered should not be viewed as deterrents but perceived as steps towards reaching the ultimate goal of creating a learning platform as popular as Facebook. However, it must be borne in mind that technology alone cannot ensure the development of this aspired platform. The concerted effort of all stakeholders is pivotal in lending support for this cause. After all, TPD is not only aimed to improve teacher practice but also to bring about school improvement.

\section{Acknowledgment}

This article is based on a research project (Code number: UKM-GUP-TMK-08-03-310) funded by a research grant provided by the National University of Malaysia.

\section{References}

Adey, P. (2004). The professional development of teachers: Practice and theory. Dordrecht, The Netherlands: Kluwer Academic Publishers.

Azian T. S. Abdullah (2006). Deconstructing secondary education: The Malaysian Smart School initiative. Paper presented at the 10th SEAMEO INNOTECH International Conference, Quezon City, Philippines. [verified 9 May 2010] http: / / www.seameoinnotech.org/ic06/download/Azian\%20Abdullah\%20-\%20full\%20paper.doc 
Barton, R. \& Haydn, T. (2006). Trainee teachers' views on what helps them to use information and communication technology effectively in their subject teaching. Journal of Computer Assisted Learning, 22(4), 257-272.

BECTA (2009). Continuing professional development in ICT for teachers: A literature review. [verified 9 May 2010] http: / / research.becta.org.uk/index.php?section=rh\&catcode=_re_rp_02\&rid=17359

Bismillah Khatoon Abdul Kader (2008). Malaysia's experience in training teachers to use ICT. In E. Meleisea (Ed.), ICT in teacher education: Case studies from the Asia-Pacific region (pp. 61-66). Bangkok: UNESCO Publication. [verified 9 May2010; 2.4 MB] http: / / unesdoc.unesco.org/images/0015/001567/156757e.pdf

Borko, H. \& Putnam, R. T. (1995). Expanding a teacher's knowledge base: A cognitive psychological perspective on professional development. In R. T. Guskey \& M. Huberman (Eds.), Professional development in education: New paradigms and practices (pp. 35-66). New York: Teachers' College Press.

Borko, H., Elliot, R. \& Uchiyama, K. (2002). Professional development: A key to Kentucky's educational reform effort. Teaching and Teacher Education, 18, 969-987.

Brinkerhoff, J. (2006). Effects of a long-duration professional development academy on technology skills, computer self-efficacy, and technology integration beliefs and practices. Journal of Research on Technology in Education, 39(1), 22-43.

Brown, J. S. \& Duguid, P. (2000). The social life of information. Boston: Harvard Business School Press.

Bullough, R. V., Burbank, M., Gess-Newsome, J., Kauchak, D. \& Kennedy, C. (1998). What matters most: Teaching for America's future? A faculty response to the Report of the National Commission on Teaching and America's future. Journal of Education for Teaching, 24(1), 7-32.

Cloke, C. \& Sharif, S. (2001). Why use information and communication technology? Some theoretical and practical issues. Journal of Information Technology for Teacher Education, 10(1-2), 7-18.

Compeau, D. R. \& Higgins, C. A. (1995). Computer self-efficacy: Development of a measure and initial test. MIS Quarterly, 19(2), 189-211.

Fischer, G. \& Giaccardi, E. (2006). Meta-design: A framework for the future of end user development. In H. Lieberman, F. Paternò \& V. Wulf (Eds.), End user development empowering people to flexibly employ advanced information and communication technology (pp. 427457). Dordrecht, The Netherlands: Kluwer Academic Publishers.

Davis, F. D. (1989). Perceived usefulness, perceived ease of use, and user acceptance of information technology. MIS Quarterly, 13(3), 319-342.

Davis, F. D., Bagozzi, R. P. \& Warshaw, P. R. (1992). Extrinsic and intrinsic motivation to use computers in the workplace. Journal of Applied Social Psychology, 22, 1111-1132.

Day, C. (1999). Developing teachers: The challenges of lifelong learning. London: Falmer Press.

Ely, D. P. (1999). Conditions that facilitate the implementation of educational technology innovations. Educational Technology, 39(6), 23-27.

Frost \& Sullivan (2004). Benchmarking of the Smart School integrated solution. Multimedia Development Corporation and Ministry of Education, Malaysia. [verified 9 May 2010; 1.7 MB] http: / / www.mscmalaysia.my/codenavia/portals/msc/images/pdf/ssbenchmarking.pdf

Fullan, M. \& Steigelbauer, S. (1991). The new meaning of educational change. London: Cassell. 
Garet, M. S., Porter, A. C., Desimone, L., Birman, B. F. \& Kwang, S.-Y. (2001). What makes professional development effective? Results from a national sample of teachers. American Educational Research Journal, 38(4), 915-945.

Gebhard, J. (2005). Teacher development through exploration: Principles, ways, and examples. TESL-EJ, 9(2), 1-15. http:/ / tesl-ej.org/pdf/ ej34/a4.pdf

Goodhue, D. L. \& Thompson, R. L. (1995). Task-technology fit and individual performance. MIS Quarterly, 19(2), 213-236.

Guskey, T. (1995). Professional development in education: In search of the optimal mix. In T. Guskey \& M. Huberman (Eds.), Professional development in education: New paradigms and practices (pp. 114-132). New York: Teachers College Press.

Guskey, T. \& Huberman, M. (Eds.) (1995). Professional development in education. New York: Teachers College, Columbia University.

Hajar Mohd. Nor (2005). Conditions facilitating the implementation of information and communication technology (ICT) integration in the Malaysia Smart Schools. Unpublished PhD, Universiti Putra Malaysia, Serdang, Selangor.

Holland, H. (2005). Teaching teachers: Professional development to improve student achievement. Teaching Teachers, 3(1). http:/ / www.eric.ed.gov:80/ERICDocs/data/ ericdocs2sql/ content_storage_01/0000019b/80/1b/ce/7c.pdf

Hopkins, D., West, M. \& Ainscow, M. (1996). Improving the quality of education for all. London: David Fulton.

Hsu, M. K., Wang, S. W. \& Chiu, K. K. (2009). Computer attitude, statistics anxiety and selfefficacy on statistical software adoption behavior: An empirical study of online MBA learners. Computers in Human Behavior, 25, 412-420.

Jaber, W. E. \& Moore, D. M. (1999). A survey of factors that influence teacher's use of computer based technology. International Journal of Instructional Media, 26(3), 256-266.

Joyce, B. \& Weil, M. (1986). Models of teaching (3rd ed.). Englewood Cliffs, NJ: Prentice-Hall.

Joyce, B. \& Showers, B. (1988). Student achievement through staff development (1st ed.). New York: Longman.

Kay, R. (2007). The impact of preservice teachers' emotions on computer use: A formative analysis. Journal of Educational Computing Research, 36(4), 455-479.

Lee, K. W. (2007). ESL teacher professional development and curriculum innovation: The case of the Malaysian Smart School project. Unpublished PhD Thesis. Department of Linguistics and English Language, Lancaster University, United Kingdom.

Mathieson, K. (1991). Predicting user intentions: Comparing the technology acceptance model with the theory of planned behavior. Information Systems Research, 2(3), 173-191.

Ministry of Education (1997). The Malaysian smart school implementation plan. Ministry of Education, Kuala Lumpur.

Mishra, P. \& Koehler, M. J. (2006). Technological pedagogical content knowledge: A framework for teacher knowledge. Teachers College Record, 108(6), 1017-1054.

Mokhtar Hj. Nawawi, Ahmad Fauzi M. Ayub, Wan Zah W. Ali, Aida Suraya M. Yunus \& Rohani Ahmad Tarmizi (2005). Teachers' perceptions on the conditions facilitating the use of computers in teaching mathematics. Malaysian Online Journal of Instructional Technology (MOJIT), 2(3), 88-98. [verified 9 May 2010] http:/ / pppjj.usm.my/mojit/articles/pdf/ Dec05/11\%20-\%20MATHEMATICS_TEACHERS_PERCEPTIONS-f.pdf 
Moon, J. \& Kim, Y. (2001). Extending the TAM for a world-wide-web context. Information $\mathcal{E}$ Management, 38, 217-230.

O'Hanlon, C. (2009). Resistance is futile. T.H.E. Journal, 36(3), 32-36. http: / / thejournal.com/articles / 2009/03/01/resistance-is-futile.aspx

Sham Ibrahim (2003). The use of multimedia software in instruction among secondary school teachers in the district of Jelebu, Negeri Sembilan. Unpublished MA Thesis. Universiti Putra Malaysia, Serdang, Malaysia.

So, H. J. \& Kim, B. (2009). Learning about problem based learning: Student teachers integrating technology, pedagogy and content knowledge. Australasian Journal of Education Technology, 25(1), 101-116. http: / / www.ascilite.org.au/ajet/ajet25/ so.html

Sun, H. \& Zhang, P. (2006). The role of moderating factors in user technology acceptance. International Journal of Human-Computer Studies, 64, 53-78.

Teo, T., Lee, C. B. \& Chai, C. S. (2007). Understanding pre-service teachers' computer attitudes: Applying and extending the technology acceptance model. Journal of Computer Assisted Learning, 24, 128-143.

Thang, S. M., Murugaiah, P., Hall, C. \& Hazita Azman (2009a). Teachers' views of their involvement in an online community of practice project. CALL-EJ Online, 11(1). http: / / www.tell.is.ritsumei.ac.jp/ callejonline/journal/11-1/ siewming.html

Thang, S. M., Murugaiah, P., Krishnasamy, P., Azizah Yaa'cob \& Hazita Azman (2009b). An investigation of the ICT challenges and practices of Malaysian smart school teachers. Malaysian Journal of Information, Communication and Technology, 1, 50-73. [verified 9 May 2010] http: / / myjict.wordpress.com/volume-1-2009/

Venkatesh, V., Morris, M. G., Davis, G. B. \& Davis, F. D. (2003). User acceptance of information technology: Towards a unified view. MIS Quarterly, 27(3), 425-478.

Associate Professor Thang Siew Ming PhD (Nottingham)

School of Language Studies and Linguistics, Faculty of Social Sciences and Humanities

Universiti Kebangsaan Malaysia, 43600 Bangi, Selangor, Malaysia

E-mail: thang@pkrisc.cc.ukm.my Web: http:/ / pkukmweb.ukm.my/ smthang/

Puvaneswary Murugaiah, School of Distance Education

Universiti Sains Malaysia, 11800 USM, Pulau Pinang Malaysia

Email: email : ampuva@usm.my

Web: http: / / pppij.usm.my/ page\%20puvaneswary\%20marugaiah.html

Lee Kean Wah, School of Education and Social Development

Universiti Malaysia Sabah

Locked Bag No. 2073, 88999, Kota Kinabalu, Sabah, Malaysia

Hazita Azman, Tan Lay Yean, Lee Yit Sim

School of Language Studies and Linguistics, Faculty of Social Sciences and Humanities Universiti Kebangsaan Malaysia, 43600 Bangi, Selangor, Malaysia 